\title{
NOVEL NON-MAGNETIC STEEL FOR HIGH-PERFORMANCE DRILLING AND LOGGING OPERATIONS
}

\author{
P. V. Bravkov ${ }^{1}$, R. Z. Gusmanov², O. V. Zhdaneev'1,3, A. L. Sapunov ${ }^{4}$ \\ ${ }^{1}$ Russian Energy Agency of RF Ministry of Energy (Moscow, Russia) \\ ${ }^{2}$ PKF-Gazneftemash LLC (Moscow, Russia) \\ ${ }^{3}$ Gubkin National University of Oil and Gas (Moscow, Russia) \\ 4 "Ruspolymet" Group of Companies (Kulebaki, Russia)
}

E-mail: Bravkov@rosenergo.gov.ru; R.Gusmanov@pkf-gnm.ru; Zhdaneev@rosenergo.gov.ru; A.Sapunov@ruspolymet.ru

\section{AUTHOR'S INFO}

\section{P. V. Bravkov, Head of the Dept.}

"Industrial Technologies for Energy Sector", Technology Development Center

R. Z. Gusmanov, CEO

O. V. Zhdaneev, Cand. Phys.-Math.

Head of Technology Development

Center of Russian Energy Agency

of RF Ministry of Energy, Associate

Prof. of the Chair of Global

Economics and Energy Policy

A. L. Sapunov, Technical Director

\section{Key words:}

non-magnetic steel, oil and gas instrument engineering, hard-torecover reserves (HTR reserves), drilling of wells, bottomhole assembly (BHA).

\author{
A B S T R ACT
}

\begin{abstract}
The paper presents the results of realized project aimed on development of the Russian non-magnetic steel for borehole equipment. Development specialists of high-tech equipment for the RF fuel and energy complex (FEC) have noted the complete dependence on deliveries of foreign non-magnetic steels from EU countries, China, USA. This dependence on delivery of import products increases the risks of both operating activity (due to trade restrictions) and economical efficiency of the FEC enterprises (Russian ruble exchange rate grew by $\sim 30 \%$ to Euro in 2020). It concerns users of mineral resources, oil service companies, developers and manufacturers of high-tech equipment for boreholes drilling as well geophysical researches. Possibility of establishment of non-magnetic steel production in Russia was analyzed, the plan for realization of this project was prepared, the technical and project risks were evaluated, the industrial demand for non-magnetic steel was assessed, the industrial technical requirements and testing techniques were developed. The cooperation chain including purchaser, manufacturer of bar products of non-magnetic steel and producer of non-magnetic steel itself was formed in 2020. Three pilot melts of non-magnetic steel (totally $18 \mathrm{t}$ ) were conducted and bars of different diameters (from 35 to $140 \mathrm{~mm}$ ) were forged. The plant laboratorial testing displayed the following bar parameters: yield strength 1,093 MPa; tensile strength 1,155 MPa; impact energy $242 \mathrm{~J}$. This steel as also characterized by resistance to intergranular corrosion. Relative magnetic permeability made 1.003 . The laboratorial tests were conducted in accordance with ASTM techniques. The following equipment range was fabricated: non-magnetic subs Flow-Sub, non-magnetic heavy-weight drill collars etc. At present time the field testing takes place in the oil and gas provenances of Western Siberia, Yamal and in Volga-Ural region within the framework of drilling of oil and gas wells.
\end{abstract}

\section{Introduction}

Lowering of oil and gas production in Russia can start already in the beginning of 2020-ies owing to depletion of conventional reserves and lack of new discovered resources. This forecast is based on the target indicators of oil and gas production in the RF Energetic strategy until 2035 that was approved by the order No. 1523-p dated 09 June 2020 of RF Government. The problem is complicated by the current geological situation [1] with limited access to financial investments and new geological exploration technologies for oil and gas deposits (e.g. rotary steerable system, telemetry and measuring system for drilling, geophysical equipment). Development of equipment and technologies for efficient extraction of hard-to-recover (HTR) resources of raw hydrocarbons (Bazhenovskaya and Domanikovaya series, high-viscous oils form Tatarstan and Timano-Pechory) is the priority task for the nearest years, because volume of reserves, bedding conditions and presence of infrastructure support economical efficient development of deposits [2].

Production of non-magnetic steels and alloys [2,3] is one of the key elements of oil and gas machine-building; this production is not put into practice in Russia. These materials are widely used in fabrication of geological steering, telemetry and measuring systems for drilling of oil and gas wells, in such components as dip circle modules, shells of telemetry systems, shells of rotary steerable systems, isolated heavy-weight drill collars and in other devices and sensors (the total production range includes more than 100 applications) [2].

\section{Non-magnetic steel in oil and gas instrument engineering}

The industrial investigation was conducted in order to solve the problem of appearance of domestic non-magnetic steel at Russian market. This investigation examined the technical and methodical base for production of nonmagnetic steels in Russia and evaluated the prospects of demand and technical requirements for this product.

The producers of geological steering equipment as well as telemetry and measuring systems for drilling noted the complete dependence on delivery of foreign non-magnetic steels Magnadur 501, Magnadur 601, P550, P650, StaballoyAG17, SLW-3 and their analogues from Western Europe countries and China [4]. This fact does not allow to increase the total level of Russian content in sensors of bottomhole assemblies (BHA) above $70 \%$ in the structure of product cost. Absence of common technical requirements 


\section{Meeting at RF Ministry of Energy}

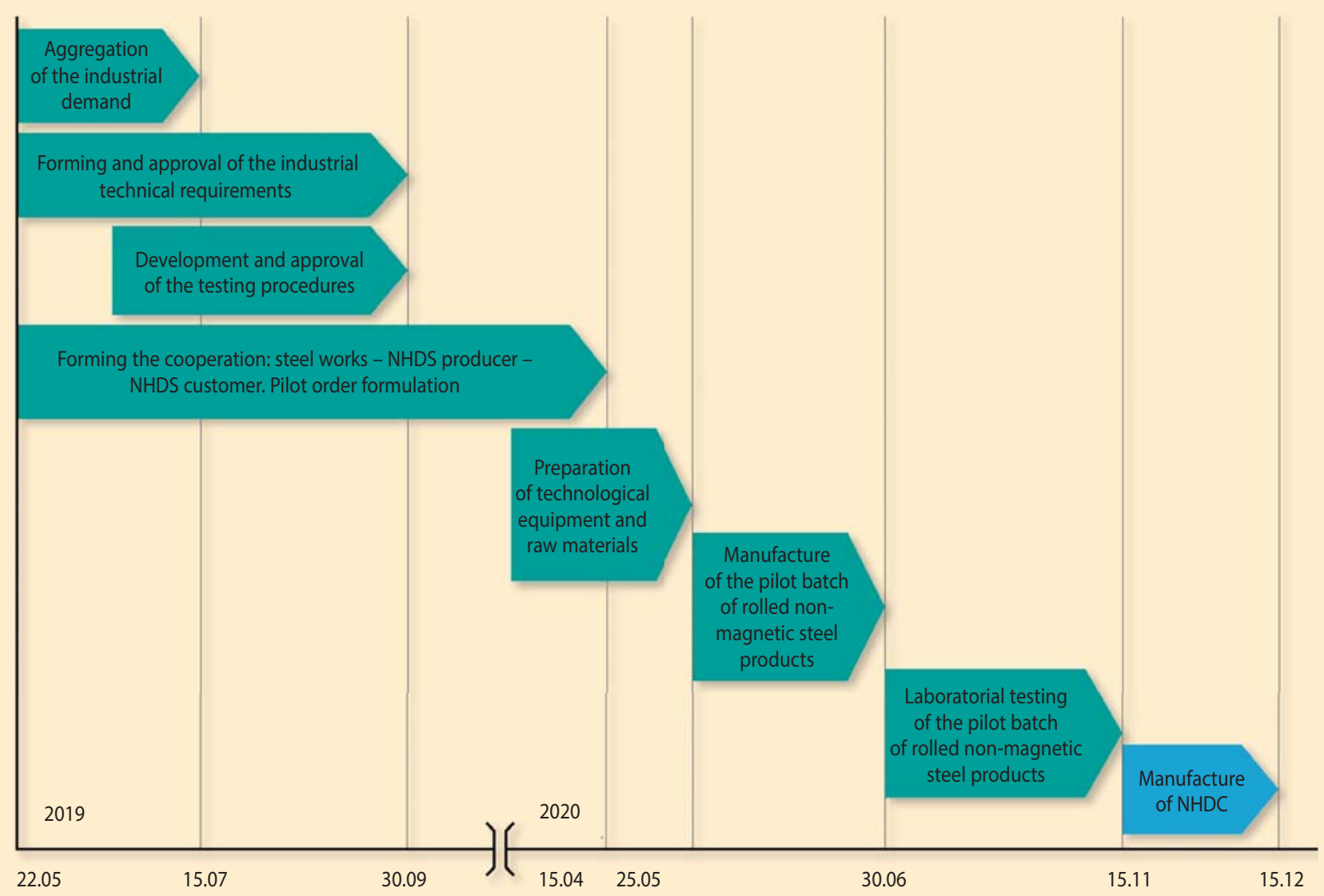

Fig. 1. The main milestones of the Roadmap realization for the project of domestic non-magnetic steel development

and testing techniques for rolled products of non-magnetic steels was noted; it leads to incomplete or partial understanding of the requirements for parameters of experimental and engineering works and technical-economical substantiation of the project. Necessity of harmonization of the requirements of standards GOST 15150-69, 5632-2014, 5632-72 and ASTM as well as development of industrial technical specifications was revealed.

It was determined during the industrial conference with participation of representatives from developers and producers of oil and gas equipment as well as metallurgical specialists (the RF Ministry of Energy protocol No. PC-166/1pr dated 22.05.2019) that the domestic steel grade 08Kh18N6AG10S (08X18H6АГ10C in Russian designation) is the most similar analogue of required non-magnetic steel in its technical parameters. However, this steel is not manufactured by the works which could provide it based on their technological structure; such production at these enterprises was estimated as not economical efficient [5].

To initiate works for decrease of dependence of Russian high-tech equipment (dip circle modules, telemetry and measuring systems) for drilling of oil and gas wells on deliveries of foreign non-magnetic steels, the road map of starting the production of such materials in Russia was developed. Its main stages and calendar schedule are presented on the fig. 1.
The following key technical and designing risks were determined: presence of the order for manufacture of products made in Russia of pilot batch of non-magnetic steel bars; adequacy of competence levels of engineering staff and workers to provide melting of stainless steels alloyed by nitrogen; presence of technological equipment meeting the requirements of pilot melting (ladle size, radial forging machine, laboratorial equipment, technical control department etc.); presence of cooperation chains for delivery management of raw materials and for melting; reliability of laboratorial tests; final correspondence of the samples taken from pilot batch to the approved industrial technical requirements as a result.

\section{Production of non-magnetic steels in Russia: requirements: demand, challenges}

Evaluation of industrial demand for non-magnetic steels for RF fuel and energy complex (FEC) until 2030 was conducted within the framework of the Roadmap measures. The following factors of oil and gas industry development were accepted in calculation of FEC needs:

- Amount of horizontal wells drilled in 2019 - 3701 [6];

- Amount of inclined directed wells drilled in $2019-$ 8482 [7]; 


\begin{tabular}{|c|c|c|c|c|}
\hline \multirow[b]{2}{*}{ Parameters } & \multicolumn{2}{|c|}{ Values } & \multicolumn{2}{|c|}{ Testing technique } \\
\hline & $\begin{array}{c}1 \text { st Group of steels } \\
(\geq 758 \mathrm{MPa})\end{array}$ & $\begin{array}{c}2^{\text {nd }} \text { Group of steels } \\
(\geq 965 \mathrm{MPa})\end{array}$ & Research method & $\begin{array}{l}\text { Location of testing } \\
\text { sample }\end{array}$ \\
\hline \multirow{2}{*}{ Yield strength, $0.2 \%$} & $\varnothing \leq 175 \mathrm{~mm}: \geq 758 \mathrm{Mpa}$ & $\varnothing \leq 254 \mathrm{~mm}: \geq 965 \mathrm{MPa}$ & ASTM A370 $21^{\circ} \mathrm{C}$ & \multirow{7}{*}{$\begin{array}{l}1 \text { inch ( } 25 \mathrm{~mm} \text {, all in } \mathrm{SI}) \\
\text { from external diameter } \\
\text { of half radius, depend- } \\
\text { ing on what is closer to } \\
\text { external surface }\end{array}$} \\
\hline & $\varnothing>175 \mathrm{~mm}: \geq 689 \mathrm{MPa}$ & $\varnothing>254 \mathrm{~mm}: \geq 897 \mathrm{MPa}$ & \multirow{3}{*}{ Longitudinal specimen } & \\
\hline Tensile strength & $\begin{array}{l}\varnothing \leq 175 \mathrm{~mm}: \geq 827 \mathrm{MPa} \\
\varnothing>175 \mathrm{~mm}: \geq 758 \mathrm{MPa}\end{array}$ & $\geq 1034 \mathrm{MPa}$ & & \\
\hline Extension & $\begin{array}{l}\varnothing \leq 175 \text { мм: } \geq 18 \% \\
\varnothing>175 \text { мм: } \geq 20 \%\end{array}$ & $\geq 20 \%$ & & \\
\hline Impact energy & $\geq 81 \mathrm{~J}$ & $\geq 120 \mathrm{~J}$ & $\begin{array}{l}\text { ASTM E23 } 21^{\circ} \mathrm{C} \\
\text { Longitudinal specimen }\end{array}$ & \\
\hline Hardness & $\geq 275 \mathrm{HB}$ & $300-400 \mathrm{HB}$ & ASTM E10 & \\
\hline Corrosion resistance & \multicolumn{2}{|c|}{ Resistance to intergranular corrosion } & ASTM A262, Practice E & \\
\hline Ultrasonic control & \multicolumn{2}{|l|}{$3,2 \mathrm{~mm}$} & $\begin{array}{l}\text { ASTM E114 or ASTM } \\
\text { A388, ASTM E428 }\end{array}$ & \\
\hline Relative magnetic permeability & \multicolumn{2}{|l|}{ Not less than 1.010} & \multirow{2}{*}{ ASTM A342 } & \\
\hline Gradient of magnetic field & \multicolumn{2}{|l|}{ Not less than $0.05 \mu \mathrm{T}$} & & \\
\hline
\end{tabular}

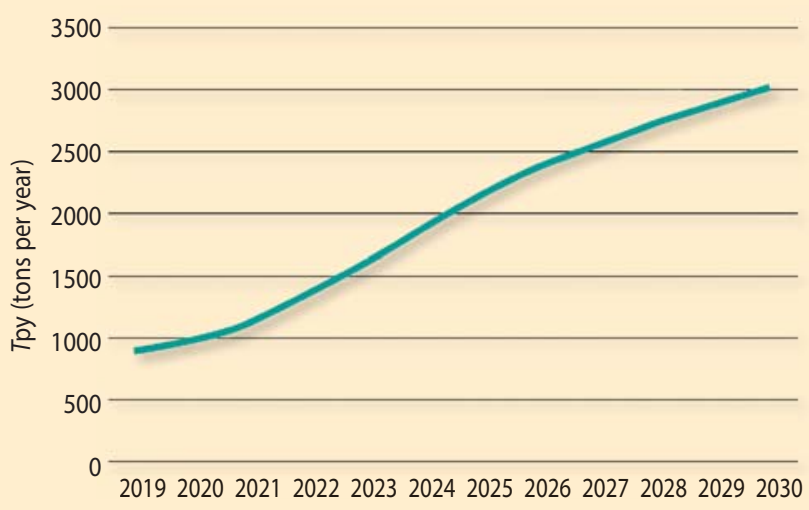

Fig. 2. Industrial demand for non-magnetic steel for oil and gas machine-building

- Amount of exploration wells drilled in 2019 - 338 [8];

- Average annual growth of operating drilling in 2009$2019-8 \%$ [2];

- HTR are developed by $25 \%$ of planned operation parameters.

Fig. 2 presents analysis of industrial demand for non-magnetic steels agreed with the producers of BHA equipment. Practical 3-fold increase of annual demand in non-magnetic steel is predicted from the current level of consumption - appr. 800 tpy.

The industrial technical requirements for non-magnetic steels were formed together with evaluation of industrial demand within the framework of the Roadmap realization. Non-magnetic steels should meet different requirements, such as high mechanical properties, high toughness, wear resistance, corrosion resistance and nonmagnetic properties [9].

Based on the practice of application, the technical requirements for rolled products are formulated both for products applied in usual operating conditions and for products that need the increased requirements to operating parameters. They include the $1^{\text {st }}$ group with yield strength more than $758 \mathrm{MPa}$ and the $2^{\text {nd }}$ group with yield strength from $965 \mathrm{MPa}$ (this steel is more alloyed in comparison with the $1^{\text {st }}$ group and has more high mechanical properties and corrosion resistance). The $1^{\text {st }}$ group includes the following imported steel grades: Magnadur 501, StaballoyAG17, P530, SLW-2, while the 2nf group - Magnadur 601, P550, P650, SLW-3 (see Table 1).

The foreign practice testifies that achievement of preset properties together with saving the cost finalize in development of steel grades corresponding to the following parameters of chemical composition: low carbon content (to $0.06 \%$ ), high manganese content (above $18 \%$ ), alloying by nitrogen, chromium content up to $21 \%$, nickel addition in wide range (depending on steel grade) and molybdenum (up to $4 \%$ ) [10].

Technical requirements are stipulated by the operating conditions of non-magnetic heavy-weight drill collars (NHDC) in wells: multi-phase liquid flow of gas, oil, water etc. in different concentrations; presence of abrasive materials, such as oil slime and formation sand; high bottomhole pressure up to $100 \mathrm{MPa}$; effect of temperatures up to $150{ }^{\circ} \mathrm{C}$; presence of aggressive media (hydrogen sulfide up to $25 \%$ (vol.); carbon dioxide up to $20 \%$, possible acidic and salty compositions; impact loads up to $1,000 \mathrm{~g}$, vibration loads up to $50 \mathrm{~g}$; loads during BHA and NHDC coupling up to $150 \mathrm{kN} \cdot \mathrm{m}[11,12]$.

The following stage in realization of the Roadmap measures was forming of cooperation "steel producer NHDC producer - NHDC purchaser"; it was actually the most durable stage - more than half of year. After discussion of technical-commercial proposals for delivery of pilot NHDC, the potential purchasers -5 leading companies in oil and gas instrument engineering - refused to participate due to possible risks of applying pre- 

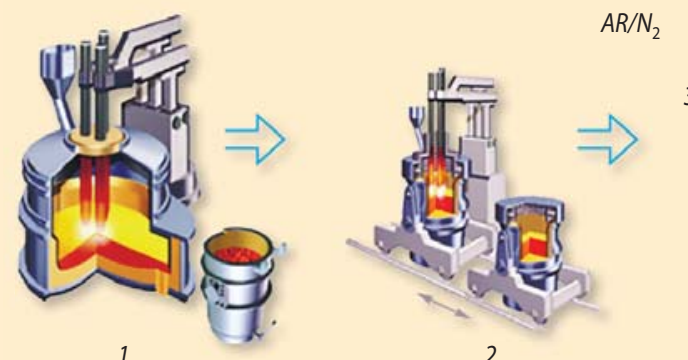

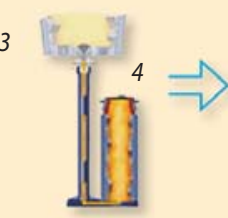

5

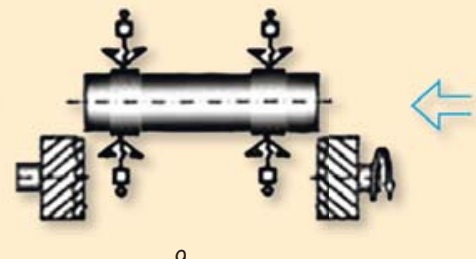

9

6

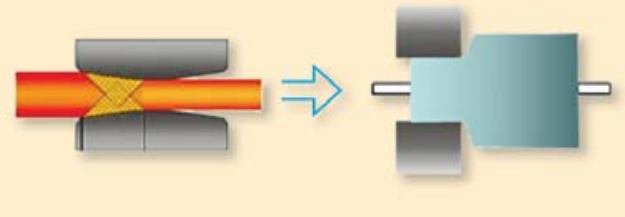

7

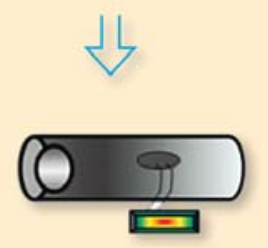

10

Fig. 3. Technological route for manufacture of non-magnetic steel rolled products :

1 - Melting; 2 - Ladle treatment; 3 - Heating stand; 4 - Vacuum degassing stand; 5 - Bottom pouring;

6 - Forging on RFM; 7 - Cold stretching; 8- Final quality control; 9 - Mechanical processing;

10 - Nondestructive testing

viously non-tested products and materials (even taking into account the positive results of laboratorial tests).

This problem is widely spread in Russian oil and gas machine-building and instrument engineering. Refuse from use of a new equipment is connected with actual transfer of operating risks (lose of a well, lost profit etc.), that can be considered as failure of technological equipment in drilling and operations inside wells, on oil service companies. These companies, in their turn, "upload" such risks to equipment producers. At present time there are no efficient protection mechanisms in the Russian legal field that can help the producers of high-tech equipment to control the risks during pilot-industrial operation of the new FEC equipment and technologies [13]. It's necessary to evaluate the possibility to form the regulatory and legal base directed on insurance of producers of high-tech equipment and technologies from the risks of failure of pilot equipment during pilot-industrial testing, i.e. using the measures of state support.

Nevertheless, the order for manufacturing the pilot NHDC batch was approved until 15.04.2020 on the base of the integrated metallurgical works Ruspolymet together with PKF-Gazneftemash LLC - the leading producer of oil and gas equipment. Technological process of manufacturing the pilot batch of non-magnetic steel bars is described on the fig. 3 .

The main stages of the technological process of nonmagnetic steel production include:

1. Melting and casting of non-magnetic steel via the following route: electric arc furnace (EAF) - ladle furnace (LF) - operating vacuum degasser (OVD) - LF - mould. EAF melting was conducted on the base of charge materials including metal wastes with definite composition. It was followed by control of chemical composition, then semiproduct was poured to LF for melt finishing in its chemical composition. During this process the ladle was transferred to OVD for oxygen blowing and deoxidation and then again in LF for final forming of chemical composition and alloying by nitrogen.

2. Heating and billeting of ingots, mechanical scarfing, cutting to measured length: $16 \mathrm{MN}$ and $35 \mathrm{MN}$ presses, scarfing machine, band sawing machine.

Billeting of forged ingots was conducted at the presses with $16 \mathrm{MN}$ and $35 \mathrm{MN}$ forces. It was aimed on manufacture of forging with solid uniform cross-section for scarfing and separating cutting on billets for their consequent plastic deformation. Scarfing of forging was made in order to remove surface forged defects that could finalize in serious metal destruction during consequent forging. The result was considered as positive one: high-quality billets were fabricated for hot plastic deformation.

3. Hot plastic deformation of billets cut to measured length: $16 \mathrm{MN}$ and $35 \mathrm{MN}$ presses, radial forging machine.

This is the most responsible operation in the forging technological cycle. The bars with diameter up to $121 \mathrm{~mm}$ and above $121 \mathrm{~mm}$ were subjected to forging via the following routes: $16 \mathrm{MN}$ press - radial forging machine and $35 \mathrm{MN}$ press $-16 \mathrm{MN}$ press respectively. To provide the preset level of mechanical properties, the final forging operations were conducted at low heating temperatures. As a result, the required number of forgings with good surface quality was produced.

4. Taking of samples, fabrication of specimens, testing of mechanical and magnetic properties, metal macrostructure and resistance to intergranular corrosion: central works laboratory (CWL).

Control of mechanical properties was conducted on longitudinal specimens fabricated from overlaps along length of billets. A sample for testing of mechanical properties and a complete transversal template for control of forging macrostructure were cut in longitudinal direction. The specimens 


\begin{tabular}{|c|c|c|c|c|}
\hline \multirow[b]{2}{*}{ Parameters } & \multicolumn{2}{|c|}{ Values } & \multicolumn{2}{|r|}{ Tests } \\
\hline & $\begin{array}{l}\text { RUMET } 960 \\
\text { ("Ruspolymet”) }\end{array}$ & $\begin{array}{l}\text { Industrial technical } \\
\text { requirements, } 2^{\text {nd }} \text { group }\end{array}$ & Method & Comment \\
\hline Yield strength, $0.2 \%$ & $1093 \mathrm{MPa}$ & $\geq 965 \mathrm{MPa}$ & \multirow{3}{*}{$\begin{array}{c}\text { ASTM A370 } 21^{\circ} \mathrm{C} \\
\text { Longitudinal specimen }\end{array}$} & \\
\hline Tensile strength & $1155 \mathrm{MPa}$ & $\geq 1034 \mathrm{MPa}$ & & \\
\hline Extension & $24 \%$ & $\geq 20 \%$ & & \\
\hline Impact energy & $242 \mathrm{~J}$ & $>120 \mathrm{~J}$ & $\begin{array}{c}\text { ASTM E23 } 21^{\circ} \mathrm{C} \\
\text { Longitudinal specimen }\end{array}$ & Average value \\
\hline Hardness & $310-340 \mathrm{HB}$ & $300-400 \mathrm{HB}$ & ASTM E10 & \\
\hline Corrosion resistance & $\begin{array}{l}\text { Resistant to } \\
\text { intergranular corrosion }\end{array}$ & $\begin{array}{c}\text { Resistant to intergranular } \\
\text { corrosion }\end{array}$ & $\begin{array}{l}\text { ASTM A262, } \\
\text { Technique E }\end{array}$ & $\begin{array}{c}\text { Sensitization heating at } 675^{\circ} \mathrm{C} \text {, } \\
1 \text { hour holding, air cooling }\end{array}$ \\
\hline Ultrasonic control & $100 \%$ & $100 \%$ & ASTM A388 & \\
\hline Relative magnetic permeability & 1,003 & Less than 1.010 & \multirow{2}{*}{$\begin{array}{l}\text { ASTM A342/ } \\
\text { A342M-2014 }\end{array}$} & On edges 1,007 \\
\hline Magnetic field gradient & Less than $0,05 \mu \mathrm{T}$ & Less than $0,05 \mu \mathrm{T}$ & & \\
\hline
\end{tabular}

for testing on extension, impact bending, magnetic permeability and magnetic field gradient, as well as for resistance to intergranular corrosion with sensitization heating were fabricated from the sample [14].

5. Final turning for setting dimension: turning lathes. Ultrasonic control (USC).

This operation was done on turning lathes after getting the positive results of testing of controlled parameters. Ultrasonic control of forgings was conducted after turning to reveal possible presence of internal metal defects.

6. Delivery control: mechanical properties, macrostructure, control of geometrical dimensions, nondestructive testing.

Delivery control was conducted by the specialists of technical control department (TCD). Correspondence of the control results verified in CWL was checked as well as correspondence of actual forging dimensions (taking into account allowances for out-of-roundness, curvature, surface cleanness etc.) and USC results to the regulating requirements for delivery. The quality certificates were issued.

7. Preparation for shipment: packaging and conservation (if required).

The complete technological cycle was realized at production facilities and up-to-date equipment of "Ruspolymet" Group of companies. Technological and production operations were provided by high-skilled Russian technologists and workers without invitation of foreign specialists. Only metallic manganese from all alloying additives was bought abroad due to absence of its production in Russia. The level of production localization for the pilot batch of non-magnetic steel makes at present time $95 \%$ by cost. The further examination of possibility of complete localization is required, meaning development of suppliers of raw materials for alloying components. The first melting of domestic non-magnetic steel in the volume 18 $\mathrm{t}$, with output of ready raw material in the volume $12 \mathrm{t}$, was conducted in May 2020. Forging operations and mechanical processing of billets were made in June 2020, aiming on obtaining of finished products that meet the requirements of approved regulating documents.

The full spectrum of laboratorial tests in correspondence with the testing technique (see values of the $2^{\text {nd }}$ group in the Table 1) was realized since July to October 2020.

The main difficulty during laboratorial testing was presented by determination of magnetic properties according to the technique ASTM A342/A342M-14, because "Ruspolymet" had not any equipment for such tests at the beginning of production. The attempts to conduct this testing in other company were not successful owing to different reasons. The equipment was specially bought for these examinations; it included the sensor of magnetic permeability of "Ferromaster" company which provided the full range of magnetic tests in accordance with the approved techniques. All other tests were conducted in the central plant laboratory using its corresponding equipment.

The results of above-mentioned tests were generalized as the following parameters for the pilot batch (see Table 3).

Analysis of qualitative parameters testifies about complete correspondence and excess of parameters of the pilot bars batch to the industrial requirements on tensile strength and yield strength, while this excess on impact energy reaches $100 \%$. These parameters were achieved due to high quality of own metal as well as properly developed and correctly executed forging technology. The rest parameters of steel quality completely meet the preset requirements. It can be concluded that bar parameters correspond the properties of the best foreign analogues, so the laboratorial tests can be recognized as successful. The quality certificate was issued by "Ruspolymet" based on the testing protocols.

The following components of BHA equipment are manufactured at present time of RUMET960 bars: nonmagnetic subs Flow-Sub, non-magnetic heavy-weight drill collars etc. Use of the components made of domestic nonmagnetic steel takes place in the oil and gas provenances 
of Western Siberia, Yamal and in Volga-Ural region within the framework of drilling of oil and gas wells. It will provide pilot operation with maximal cover of different geological conditions and drilling procedures.

The program of pilot-industrial tests (PIT) was prepared for qualitative comparison of the operating parameters of products with their foreign analogues [15]. The PIT program includes geological parameters of wells, drilling conditions, types and volumes of liquids pumped through the products, presence and concentration of solid particles both in pumped and lifted liquid, worked hours for the product in a borehole, worked hours before washing.

Taking into account the existing production facilities, the consortium "Ruspolymet" - "PKF-Gazneftemash" is able to realize up to $70 \%$ of the domestic market demand on products of non-magnetic steels for oil and gas industry.

As soon as non-magnetic steel bars were manufactured in correspondence with the standards API 7.1 and ASTM, and they meet the requirements of the foreign analogues based on conducted laboratorial tests, there is a good potential for entering the foreign markets. Based on the current macro-economical situation with weakening of RUR/ EUR and RUR/USD current rate by $30 \%$ in 2020, the domestic producers have additional competitive advantage in cost of their non-magnetic steel products manufactured in Russia.

\section{Conclusions}

Wide-scale transition to development of HTR reserves in Russian Federation determines the increasing demand on telemetry and measuring systems in drilling (growth of M/LWD equipment park is expected to 3,500 units and the volume of M/LWD equipment market will make $28 \mathrm{mlrd}$. rubles per year with annual $7 \%$ year-to-year growth) as well as on geological navigation equipment (the amount of rotary steerable systems will growth to 750 units and this market will make 15 mlrd. rubles per year with annual $7 \%$ year-toyear growth).

Wide-range distribution of domestic non-magnetic steels in Russian industry will provide stable deliveries of critically important raw material to national producers of high-tech equipment for the oil and gas industry, not depending on geopolitical situation. Presence of production facilities of such materials inside Russia will allow to control the currency risks for manufacturers of high-tech equipment for the fuel and energy complex. It will provide in its turn the competitive advantage of national innovations abroad: the part of expenses for rolled non-magnetic steels makes $15-45 \%$ in the total cost structure of oil and gas instrument engineering. The total industrial economical efficiency based on putting into practice non-magnetic steels is evaluated as $15 \mathrm{mlrd}$. rubles until 2030

\section{REFERENCES}

1. Zhdaneev O. V., Frolov K. N. On priority development directions for drilling technologies in Russia. Neftyanoe khozyaistvo. 2020. No. 5. pp. 42-48. DOI: 10.24887/0028-2448-2020-5-42-48.

2. The problems of technical policy of FEC industries in Russian Federation. Edited by Zhdaneev O. V. M., Nauka. 2020. 304 p. ISBN: 978-5-02-040824-1. DOI: 10.7868/9785020408241.

3. Zhdaneev O. V., Chuboksarov V. S. Technical policy of the Russian oil and gas industry: the tasks and priorities. Energeticheskaya politika. 2020. No. 5 (147). pp. 76-91. DOI: 10.46920/24095516_2020_5147_76.

4. High Nitrogen Steels and Stainless Steels. Manufacturing, Properties and Applications. Edited by Raj B. Woodhead Publishing. 2004. 224 p. ISBN: 9781842651292.

5. Kostina M. V., Rigina L. G. Nitrogen-bearing steels and ways of their production. Izvestiya vysshikh uchebnykh zavedeniy. Chernaya metallurgiya. 2020. No. 8 (63). pp. 606-622. DOI: 10.17073/03680797-2020-8-606-622.

6. Statistical data. The boreholes finished in horizontal drilling construction since January to December 2019. ND29 Report code number. Central Dispatching Administration of the Fuel and Energy Complex, Russian Energy Agency, Ministry of Energy of Russian Federation.

7. Statistical data. The boreholes finished in operating drilling construction since January to December 2019. ND27 Report code number. Central Dispatching Administration of the Fuel and Energy Complex, Russian Energy Agency, Ministry of Energy of Russian Federation.

8. Statistical data. The boreholes finished in exploring drilling construction since January to December 2019. ND28 Report code number. Central Dispatching Administration of the Fuel and Energy Complex, Russian Energy Agency, Ministry of Energy of Russian Federation.

9. Ricci A., Williams T., McDonnell W., Collins A. Alternative Sensitization Test Method for Austenitic Stainless Steels Used as Non-Magnetic Drill Collars. NACE International. 2020. June. pp. 1488-1502.

10. Gavriljuk V. G., Berns H. High Nitrogen Steels: Structure, Properties, Manufacture, Applications. Berlin; Heidelberg; New York: Springer-Verlag. 1999. 379 p.

11. Liu Y., Sun Z. Non-magnetic drill collar failure analysis and prevention measures. IOP Conference Series: Materials Science and Engineering. 2018. August. Vol. 397. pp. 1-6. DOI: 10.1088/1757899x/397/1/012061.

12. Albdiry M. T., Almensory M. F. Failure analysis of drill string in petroleum industry: a review. Engineering Failure Analysis. 2016. March. Vol. 65. pp. 74-85. DOI: 10.1016/j.engfailanal.2016.03.014.

13. Valiullin I. M., Andreeva N. N., Belokhvostova M. S. Managing the replacement of import products by domestic techniques and technologies. Neftyanoe khozyaistvo. 2015. No. 5. pp. 18-21.

14. Xu L., Li H., Zheng H., Lu P., Feng H., Zhang S., Jiang Z. Effects of nitrogen content on pitting corrosion resistance of non-magnetic drill collar steel. Journal of Iron and Steel Research International. 2020. No. 27. pp. 1466-1475. DOI: 10.1007/s42243-02000428-7.

15. Herrera C., Seifert M., Niederhofer P. Development of a New High Interstitial non-Magnetic Stainless Steel for Oil and Gas Applications. NACE International. 2020. June. pp. 635-646. 